\title{
The Syntactic Structure of the VP in Kihema
}

\author{
John Mwesigwa Mugisa \\ University of KwaZulu-Natal, \\ E-mail: johnmugisa@yahoo.com
}

\begin{abstract}
The Verb Phrase consists of a predicate and argument(s). Predicates attribute to individuals or things relations, actions and so on whereas arguments identify individuals, things, etc. The number of arguments, usually NPs, depends on the idiosyncratic property of the verb involved, that is, the verb's inherent lexico-semantic properties or valencies. Valencies reflect a language-specific way of conceptualizing the class or processes denoted by a given verb. This article provides an account of the syntactic properties of arguments that appear within the VP in Kihema, a Bantu language spoken in the north-eastern province of Ituri in the Democratic Republic of Congo. The Kihema data show that Kihema is, like English and many Bantu languages, a VO-language in that, on the surface, objects, prepositional phrases, sentential complements, etc. follow the verb. Furthermore, the data show that Kihema is a symmetrical object type language in that all post-verbal NPs are true direct (or, primary) objects. This means that in Kihema multiple post-verbal NPs may display 'primary object' syntactic properties. A primary object is one that shows syntactic properties of cliticization, passivizability, extractability (relativizability), etc. For example, cliticization, or object marking, takes place when primary objects are replaced by a corresponding clitic pronoun infix in the verbal complex, or "Object Clitic Pronoun" (OCP), while passivizability allows the object of an active sentence to become the subject of the corresponding passive sentence, and the subject optionally becomes the oblique PP introduced by the preposition $n a$ (the so-called by-phrase). In Kihema, the passive suffix $w$-is attached to the verb. Finally, relativization means that an empty operator is able to move from object position to SpecCP of the relative clause.
\end{abstract}

Keywords: syntax, verb phrase, Kihema, symmetrical object language, descriptive grammar

\section{Introduction}

Nurse and Philippson (2003:130) state that "the elementary syntactic structure of sentences can be understood as the main concern of the structural and syntactic sub-classification of verbs". This article provides an account of the structure of the VP in Kihema, a Bantu language spoken in the north-eastern province of Ituri in the Democratic Republic of Congo. Firstly, I present a description of the possible complements that can occur with certain verbs. Secondly, I examine the order in which various objects adjacent to the verb occur. Lastly, I examine whether these various objects adjacent to the verb attest the properties of a direct object. This will allow me to determine whether Kihema can be characterized as a genuine symmetrical object language (cf. Bresnan \& Moshi 1990). The final section of the article presents a brief summary of the article and the conclusions reached. 


\section{The complements of the verb}

The surface order of internal arguments (complements of the verb) varies cross-linguistically vis-à-vis the predicate. In some languages, the predicate precedes the object(s), namely VOlanguages, whereas in OV-languages the object(s) precedes the predicate. Kihema is a VOlanguage, that is, in Kihema complements (objects) always come after the verbal predicate. However, like in many VO-languages, some verbs (intransitive) do not take any complements. Intransitive verbs are discussed in the following subsection.

\subsection{Complements of intransitive verbs}

Burzio (1986), Haegeman (1991) and Spencer (1991) claim there are two types of intransitive verbs, that is, unergative and unaccusative verbs. The difference between unergative and unaccusative intransitive verbs in Kihema can be illustrated by looking at the unergative verb kora "work" and the unaccusative verb hendeka "break". The sentences in (1) have the DStructure representations in (2):

a. Yohaana a-ka-kor-a.

John SP-PAST-Work-ASP

"John worked."

b. Ekirahule ki-ka-hend-ek-a.

glass SP-PAST-break-ASP

"The glass broke."

(2)

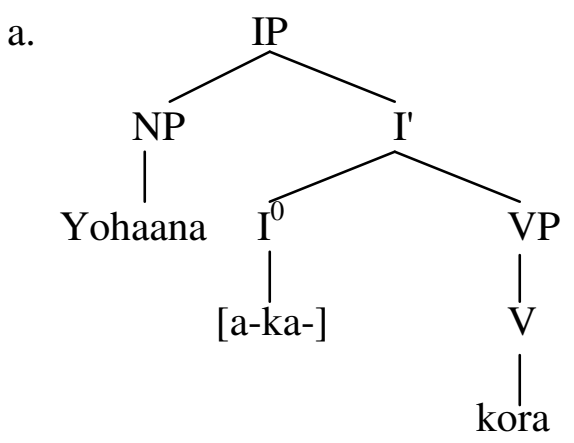

b.

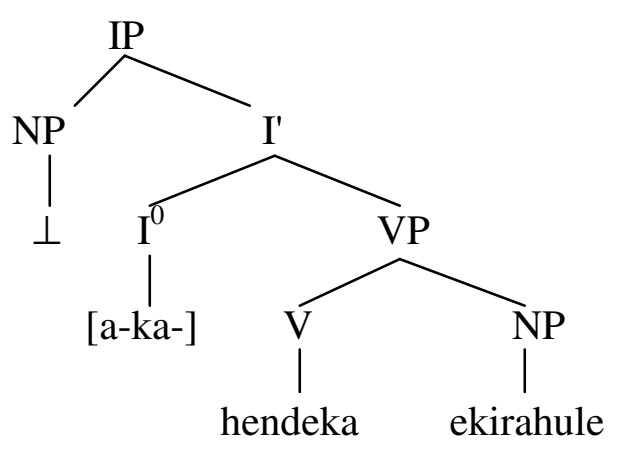

Burzio (1986:178-9) assumes that only the argument of an unaccusative intransitive is thematically an object and therefore realized inside the VP at D-Structure. This assumption can be true in Kihema as the verb in (2b) has no external argument. Burzio (1986: 184) states that "a verb which lacks an external argument fails to assign accusative case and therefore fails to theta-mark an external argument". In other words, since unaccusative verbs fail to assign an external theta-role, they therefore fail to assign structural case to an object position. Consequently, in (2b) ekirahule "a glass" will not be assigned case unless it moves to the subject position, where it will receive nominative case from the $\mathrm{I}^{0}$. The subjects of unergative verbs are underlying subjects with an external theta-role, whereas the subjects of unaccusative verbs are underlying objects that have moved to SpecIP at S-Structure.

In Kihema intransitive verbs can appear with a prepositional phrase (PP) as complement, as illustrated in (3): 
(3)
a. Munyalizi a-ka-zin-a ha mkoro.
Munyalizi SP-PAST-sing-ASP at ceremony
"Munyalizi sang at the ceremony."
b. Maria a-ka-iruk-a n' omwaana.
Mary SP-PAST-run-ASP with child
"Mary ran with the child."

\subsection{Complements of transitive verbs}

If a VP has a transitive verb as its head, the verb must take an NP-complement. Kihema attests transitive verbs that require obligatorily an NP-complement, as illustrated in (4):

(4) a. Paulo a-ka-samb-a omupira.

Paul SP-PAST-kick-ASP ball

"Paul kicked the ball."

b. Kabona a-ka-ang-a omukazi-we.

Kabona SP-PAST-divorce-ASP wife-his

"Kabona divorced his wife."

The sentences in (5), however, are ungrammatical, since the verbs appear without complements. Considering the classification of such verbs as transitive, complements are obligatory.
a. *Abala a-ka-samb-a.
Abala SP-PAST- kick-ASP
"Abala kicked."
b. *Ateenyi a-ka-aang-a.
Ateenyi SP-PAST-divorce-ASP
"Ateenyi divorced."

Transitive verbs can also allow the occurrence of a PP as long as it follows the direct object, as illustrated in (6):

(6) a. Paulo a-ka-tung-a esente omu kitunga.

Paul SP-PAST- find-ASP money in basket

"Paul found money in the basket."

b. Zonobia a-ka-nag-a amagita ha rugudo.

Zonobia SP-PAST- throw-ASP oil on road

"Zonobia threw oil on the road."

\subsection{Complements of ditransitive verbs}

In Kihema, as in many Bantu languages, there is a group of verbs that take double objects, socalled ditransitive verbs. As will be discussed in section four, both of these objects are primary objects. In this section, the aim is to show which verbs can appear with double 
objects. In (7) we see the verbs -ha "give" and -tuma "send" occurring with two obligatory NP object complements:
a. Kente a-ka-h-a Komunkemba ekisembo.
Kente SP-PAST- give-ASP Komunkemba gift
"Kente gave Komunkemba the gift."
b. Paulo a-ka-tum-a omukazi ameizi.
Paul SP-PAST- send-ASP woman water
"Paul sent the woman the water."

In transitive applicative constructions, that is, applicative constructions derived from a transitive base verb, the derived ditransitive verb can take two NP object complements (Mugisa 2005). Here, I merely provide illustrations of ditransitive verbs in Kihema derived by means of the applicative:
a. Kyaligonza a-ka-gu-ur-a nyina engoyi.
Kyalingonza SP-PAST-buy-APP-ASP his-mother clothes
"Kyaligonza bought his mother clothes."
b. Embwa e-ka-cumb-ir-a enkoko ebihimba. dog SP-PAST-Cook-APP-ASP hen beans
"The dog cooked the beans for the hen."

With certain ditransitive verbs, the second complement is a PP instead of an NP, as illustrated in (9):
a. Omukazi a-ka-t-a ebyokulia ha meza.
woman SP-PAST-put-ASP food on table
"The woman put food on the table."
b. Omwaana a-ka-nag-a omupira ha rusu.
child SP-PAST- throw-ASP ball on roof
"The child threw the ball on the roof."

From the examples above, it should be noted that PP complements always follow NP compliments, if both types occur in the same clause (see examples 21a-b and 22a-b).

Since the applicative can also be formed from ditransitive verbs in Kihema, some Kihema verbs can allow up to three complements. In the following examples in (10), the second NP and the PP are complements of the base verb, whereas the first NP is the applied object NP introduced by the applicative:

(10) a. Petero a-ka-he-er-a Kaboyo esente mu nkomo.

Peter SP-PAST-give-APP-ASP Kaboyo money in jail

"Peter paid the bail in the prison for Kaboyo."

Lit.: "Peter gave the money in the prison for Kaboyo." 
b. Ananiya a-ka-twek-er-a omukazi-we engoyi mw' irwaro. Ananiya SP-PAST-Send-APP-ASP wife-his clothes in hospital "Ananiya sent the clothes to his wife in the hospital."

The Kihema applied verb heera "give on behalf of someone" (I will use "give for") can also take a third NP complement, as illustrated in (11):
Omuseija a-ka-he-er-a omukazi omwaana omubazi.
man SP-PAST-give-APP-ASP woman child medicine
"The man gave the child medicine for the woman."
Lit.: "The man gave for the woman to the child the medicine."

In Kihema, adjectival phrases (AP) are rare in post-verbal position. Only the verb "to be" allows such a construction, as illustrated in (12):
a. Yonesani a-li mkoto.
Yonesani s/PREs-be big/fat/tall
"Yonesani is tall."
b. Kamwiima a-li mgufu muno.
Kamwiina S/PRES-be short very
"Kamwiima is very short."
c. Nyangoma a-li murungi muno.
Nyangoma s/PREs-be beautiful very
"Nyangoma is very beautiful."

In most cases, what is expressed by means of an adjectival complement in languages like English is often expressed in Kihema by means of stative verbs, as single lexical items. For instance, -reiha, "to be tall", -gufahara "to be short" and -semera "to be beautiful" correspond to the adjectives mkoto "tall/fat/big", mgufu "short" and murungi "beautiful".
(13) a. Yonesani a-ka-reih-a.
Yonesani SP-PAST-be/tall-ASP
"Yonesani is tall."
b. Kamwiima a-ka-gufahar-a.
Kamwiima SP-PAST-be/short-ASP
"Kamwiima is short."
c. Nyangoma a-ka-semer-a.
Nyangoma SP-PAST-be/beautiful-ASP
"Nyangoma is beautiful."

In a very limited number of cases, adverb phrases (AdvP) appear within the verb phrase in Kihema, and may be preceded by an NP, as illustrated in $(14)^{1}$ :

\footnotetext{
${ }^{1}$ Kihema has a rule of morphological reduplication that turns adjectives into adverbs.
} 
a. Yohaana a-ka-zin-a bwango bwango.

John SP-PAST-sing-ASP quick quick

"John sang quickly."

b. Kabarole a-ka-lim-a omusiri mpora mpora.

Kabarole SP-PAST-plough-ASP field slow slow

"Kabarole ploughed the field slowly."

The next category of complements that appear with the verb in Kihema verb phrases is the sentential, or clausal, complement (CP). The latter can appear with both transitive and intransitive verbs, as illustrated in (15):

a. Zadoki a-ka-gamb-a ngu abaana ba-ka-fw-a.

Zadoki SP-PAST-Say-ASP that children SP-PAST-die-ASP

"Zadoki said that the children died."

b. Tibasima a-ka-rwaan-a a-himb-ir-e ensaho.

Tibasima SP-PAST-fight-ASP SP-carry-APP-SUBJ sack

"Tibasima fought while he was carrying the sack."

Lit.: "Tibasima fought he is carrying the sack for himself."

c. Bezo a-ka-fw-a a-gwedzeg-ir-e.

Bezo SP-PAST-die-ASP sP-deep-asleep-APP-SUBJ

"Bezo died while he was deep asleep."

Lit.: "Bezo died he is deep asleep for himself."

The sentences in (15b-c) are different from (15a). In the latter, the sentence contains a complementizer, $n g u$ "that", whereas the sentences $(15 \mathrm{~b}-\mathrm{c})$ do not contain any complementizers but can nevertheless be translated into English using the complementizer "while". This interpretation is the result of the specific mood of the second verb (subjunctive), which is different from the mood of the first verb (indicative). According to Vitale (1981:65), the conjugated Kihema verbs ahimbire "he is carrying" and agwedjegire "he is deeply asleep" in (15b-c) appear with a subjunctive suffix $-e$ preceded by the applicative morpheme -ir- to mean that the agent is the beneficiary of his/her own action. The subject prefix of the subjunctive verb agrees with the gender and person of the subject of the main verb.

(16) Mu-ka-iruk-a mu-hute-ir-e.

2PRS.PL.PAST-run-ASP 2PRS.PL.-injure-APP-SUBJ

"You ran while you were injured."

Lit.: "You ran you are injured."

Vitale (1981) observes that such subjunctive forms are always tenseless. Moreover, if the subject of the embedded verb is the object of the matrix verb, it is replaced by its corresponding person, as illustrated in (17): 
(17)

Filipo a-ka-gur-a emotoka e-kuz-ir-e.

Philip SP-PAST- buy-ASP car sP-be/old-APP-SUBJ

"Philip bought an old car."

Lit.: "Philip bought a car [a car $]^{2}$ is old."

In (17), one has to bear in mind that only the subject prefix remains in the subordinate clause. This is because in Kihema two identical NPs cannot co-occur overtly in the same structure, as illustrated in (18):
a. $\quad$ *Petero a-ka-fw-a Petero a-gwedjeg-ir-e.
Peter SP-PAST- die-ASP Peter SP-sleep-APP-SUBJ
"Peter died while he was deeply asleep."
b. *Filipo a-ka-gur-a emotoka emotoka e-kuz-ir-e.
Philip SP-PAST- buy-ASP car car SP- be/old-APP-SUBJ
"Philip bought an old car"

Finally, I shall examine infinitival complements. Infinitive complements behave like locative complements. The infinitive in Kihema is class 15 with the nominal prefix $k u$. An infinitival complement can stand on its own within the Kihema VP, as illustrated in (19a). The verb saba "pray" in (19b) is the infinitive complement of the verb -genda "go" which in turn is the complement of the main verb -seera "want". The NP omukaba "the belt" in (19c) is the complement of the infinitive -gura "buy" which is the complement of the main verb tekereza "think".
a. $\quad$ Ente e-ka-gend-a ku-sab-a. COW SP-PAST-gO-ASP 15:pray-ASP
"The cow went to pray."
b. Enjoka e-ka-ser-a ku-gend-a ku-sab-a.
snake SP-PAST-want-ASP 15:go-ASP 15:pray-ASP
"The snake wanted to go to pray."
c. Wakame a-ka-tekerez-a ku-gur-a omukaba.
hare SP-PAST-think-ASP 15:buy-ASP belt
"The hare thought to buy the belt."

As one may notice, Kihema allows a great variety of complements to appear along with the verb in the VP. In the following section I discuss how those complements can occur together in terms of their adjacency to the verb (order).

\section{Word order of complements}

Kihema is a configurational language, that is, the complements of the verb are hierarchically ordered. For example, prepositional phrases in Kihema obligatorily appear after the NP that follows immediately after the verb, while the reverse order is ungrammatical, as illustrated in (20)-(22):

\footnotetext{
${ }^{2}$ Here [a car] is a trace or a copy.
} 
(20)

a. Omukazi a-ka-t-a ebyokulia ha meza. woman SP-PAST-put-ASP food on table "The woman put the food on the table."

b. *Omukazi a-ka-t-a ha meza ebyokulya. woman SP-PAST-put-ASP on table food "The woman put on the table the food."

(21) a. Omwaana a-ka-nag-a omupira ha rusu. child SP-PAST- throw-ASP ball on roof "The child threw the ball on the roof."

b. *Omwaana a-ka-nag-a ha rusu omupira. child SP-PAST- throw-ASP on roof ball "The child threw on the roof the ball."

(22) a. Enkende e-ka-ses-a ameizi omu nzu. monkey SP-PAST-pour-ASP water in house "The monkey poured water in the room."

b. *Enkende e-ka-ses-a omu nzu ameizi. monkey SP-PAST-pour-ASP in house water "The monkey poured in the room the water."

In the next part of this section, I discuss constructions with two post-verbal NP objects that have the thematic roles of beneficiary/goal and theme. In general, the objects of the verb are strictly ordered. The two NP objects in (23), for example, must appear in the order benefactive/goal-theme, as the opposite order is ungrammatical in Kihema:
a. Yohaana a-ka-h-a omwaana enkeito.
John SP-PAST-give-ASP child shoes
"John gave the child the shoes."
b. *Yohaana a-ka-h-a enkeito omwaana. John SP-PAST-give-ASP shoes child "John gave the shoes to the child."
c. Kyaligonza a-ka-gu-ur-a nyina engoyi. Kyalingonza SP-PAST-buy-APP-ASP his-mother clothes "Kyaliginza bought his mother clothes."
d. *Kyaligonza a-ka-gu-ur-a engoyi nyina. Kyaligonza SP-PAST-buy-APP-ASP clothes his-mother "Kyaligonza bought the clothes for his mother."

The restricted order of complements in Kihema is interesting, since not all Bantu languages behave like this. For example, Kinyarwanda, another Bantu language spoken in central Africa, attests the free order of such objects, as illustrated in (24): 
a. Omugabo y-a- ha-ye abaana enkweto.

(Kinyarwanda) man SP-PAST-give-ASP children shoes

"The man gave the children the shoes."

b. Omugabo y-a-ha-ye enkweto abaana.

man SP-PAST-give-ASP shoes children

"The man gave the shoes to the children."

However, the order of objects in Kihema is not only determined by the thematic role of the NP. Rather, if two post-verbal NPs have the thematic roles of benefactive and theme respectively, the animate NPs tend to occur before inanimate NPs. In this regard, Morolong (1977:202) discusses four possibilities to identify the occurrence of the animate and inanimate thematic roles of post-verbal NPs in Sesotho. Here I investigate Kihema ditransitive verbs in the light of these four options:

(i) If one object is benefactive and animate, and the other is a theme and inanimate; then the latter will follow the former: benefactive animate $>$ theme inanimate, as illustrated in (25) (see also $(23 \mathrm{a}, \mathrm{c})$ ):
a. Kyalimpa a-ka-gu-ur-a omukazi-we empeta.
Kyalimpa SP-PAST-buy-APP-ASP wife-his ring
"Kyalimpa bought his wife the ring."
b. *Kyalimpa a-ka-gu-ur-a empeta omukazi-we.
Kyalimpa SP-PAST-buy-APP-ASP ring wife-his
"Kyalimpa bought the ring for his wife."

(ii) If both objects are inanimate, then the benefactive comes first; benefactive inanimate > theme inanimate:

a. Maryamu a-ka-cumb-ir-a omkoro ebyokulya.

Maryamu SP-PAST-cumb-APP-ASP ceremony food

"Maryamu cooked the food for the ceremony."

b. *Maryamu a-ka-cumb-ir-a ebyokulya omkoro.

Maryamu SP-PAST-cumb-APP-ASP food ceremony

"Maryamu cooked the food for the ceremony."

(iii) If the benefactive is inanimate, and the theme animate; then the theme animate will precede the benefactive inanimate: theme animate $>$ benefactive inanimate.
a. Komunkemba a-ka-rali-z-a
abaramukati
obugenyi.
Komunkemba SP-PAST-call-APP-ASP her-sisters-in-law feast
"Komunkemba called her sisters-in-law for the feast."
b. *Komunkemba a-ka-rali-z-a obugenyi abaramukati.
Komunkemba SP-PAST-call-APP-ASP feast her-sisters-in-law
"Komunkemba called for the feast her sisters-in-law." 
The data in (27) show that in Kihema, animacy is a stronger factor in determining word order than thematic role. Although benefactives usually precede themes, the opposite word order is required if the theme is animate but the benefactive is not. This means that if two objects are NPs, one referring to a person and another to a thing, the object closest to the verb must be that referring to the person. Morolong (1977: 205) argues that

the order of benefactive inanimate/theme animate varies cross-linguistically. For example, in many Bantu languages if both NPs were animate, the benefactive would precede the theme. In Ligooli, if the benefactive is animate and the theme inanimate, both word orders are possible. On the other hand, if the benefactive is inanimate and the theme animate, only the order theme $>$ benefactive is possible.

Kihema and Sesotho are among many other Bantu languages where an animate theme must precede a benefactive inanimate. The example in (27) above illustrates this for Kihema, whereas (28) below illustrates this for Sesotho.

a. Bana ba-bitsel-tsoe lijo

(Sesotho)

children SP-PAST-Call-APP-ASP feast

"They called the children for the feast."

Lit.: "Children they were called for feast."

b. *Mokete o-bitselitsoe bana.

feast SP-PAST- call-APP-ASP children

"They called the feast for the children."

Lit.: "The feast it was called for the children."

(Morolong 1977: 203)

(iv) If both objects are animates, then the benefactive must come first; benefactive animate $>$ theme animate, as illustrated in (29):
Omugurusi a-ka-et-er-a
omukama abeisiki.
old man SP-PAST-call-APP-ASP king girls
"The old man called the girls for the king."

If the word order in (29) is reversed, as in (30),
Omugurusi a-ka-et-er-a
abeisiki omukama.
old man SP-PAST-call-APP-ASP girls king
"The old man called the king for the girls"

then the NP abeisiki "the girls" is interpreted as the benefactive, and omukama "the king," as the theme, in accordance with the requirement that a benefactive animate NP must always precede a theme animate NP.

It is important to mention that Dative applicative constructions are the most common and syntactically regular in Kihema. This construction is also attested in Chichewa and other languages. By comparison, in English, the Dative shift construction only occurs at the expense of the Dative preposition ("for") (Baker 1988:234-242). 
In the following section, I examine whether or not all post-verbal objects in Kihema are indeed direct objects.

\section{Direct object properties}

Baker (1988) distinguishes five properties of direct objects. These properties are word order, cliticization, passivization, relativization and theme deletion. Bresnan and Moshi (1990) discuss the same properties and add to the list two more properties: reciprocalization and interaction of object properties. Cliticization, or object marking, takes place when primary objects are replaced by a corresponding clitic pronoun infix in the verbal complex. Duranti (1979:32) names this clitic the "Object Clitic Pronoun" (OCP). Passivization occurs when the object of an active sentence becomes the subject of the corresponding passive sentence, and the subject optionally becomes an oblique PP introduced by a preposition (the so-called byphrase). Finally, relativization means that an empty operator (a phonologically zero relative pronoun) moves from object position to SpecCP of the relative clause.

For a start, I assume that Kihema belongs to the group of so-called "symmetrical object languages" like Kichaga (Bresnan and Moshi 1990), Kihaya (Duranti and Byarushengo 1972), Kimeru (Hodges 1977), Kinyarwanda (Kimenyi 1980), Mashi and Luyia (Gary 1977). This means that Kihema has the ability to display more than two post-verbal NPs that attest 'primary object' syntactic properties. These properties are the ability of the object to cliticize to the verb (object marking), to undergo passivization and so on. In contrast, there is also another category of languages named "asymmetrical object languages" in which only the applied object can attest all the characteristics of a direct object (cf. Baker 1988, Bresnan and Moshi 1990, Mchombo 1993 and Ngonyani 1998).

\subsection{Cliticization (object marking)}

Cliticization is one of the properties of direct objects in that only primary objects can be replaced by a corresponding clitic pronoun infix, the OCP, in the verbal complex. It is important to mention that, in Kihema, the OCP agrees in noun class with the corresponding noun. For example in (31a), the noun omubazi "medicine" is in class 3; its corresponding OCP is $g u$ of class 3. Both omukazi "the woman" and omwaana "child" belong to class 1; their corresponding OCP is $m u$.

$$
\begin{aligned}
& \text { a. Omwaana a-ka-ly-a ebyenzu. } \\
& \text { child SP-PAST-eat-ASP bananas } \\
& \text { "The child ate bananas." } \\
& \text { b. Omwaana a-ka-bi-ly-a. } \\
& \text { child SP-PAST-OCP 1-eat-ASP } \\
& \text { "The child ate them." }
\end{aligned}
$$

In Kihema, the OCP cannot co-occur with the full NP that it replaces. The sentence in (32a) below is a Kihema example in which the OCP appears without its NP, while (32b) illustrates the ungrammaticality of the co-occurrence of the OCP and its NP. 
a. Bazarwa a-ka-gonz-a omwisiki.

Bazarwa SP-PAST-love-ASP girl

"Bazarwa loved the girl."

b. *Bazarwa a-ka-mu-gonz-a omwisiki.

Bazarwa SP-PAST-OCP-love-ASP girl

"Bazarwa loved the girl."

In contrast, some Bantu languages, such as Kiswahili (Ngonyani, 1998), Kirimi and Ruwund (Woolford, 2001), Zulu (Zeller, 2004), allow the presence of both the pronominal and the NP, as illustrated by the examples in (33):

a.

$$
\begin{aligned}
& \text { Juma a-li-m-piga mtoto. } \\
& \text { Juma SP-PAST- OCP-hit-ASP child }
\end{aligned}
$$

(Kiswahili)

"Juma hit the child."

b. N-a-mu-onaa Maria.

SP-PAST-OCP-see Maria

"I saw Maria."

(Kirimi)

(Woolford, 2001:2)

c. Ku-y-iiy antu nfalâng.

(Ruwund)

INF-OCP-steal people money

"to steal money from [any or particular] people."

(Woolford , 2001: 6)

d. Ng-Ubani o-m-bona-yo?

(Zulu)

COP-who 1 a RC2 ${ }^{\text {nd }}$ SG-OCP 1 a-see-RS

"Who is it that you see?"

(Zeller, 2004: 2)

Considering examples in (32) and (33), Duranti (1977) further argues that the OCP is a pronoun that replaces a direct object in the former, and in the latter the OCP is considered as an object agreement morpheme (Woolford, 2000 and 2001). However, Zeller (2004) states that in Zulu this morpheme can be analyzed as an OCP even though it can co-occur with a full NP. Kihema allows more than one OCP to be marked on a verb. This means that both NPs can cliticize individually or together in the same context, as illustrated by the example sentences in (34):

(34) a. Enzangu e-ka-tiiz-a embeba enkeito.

cat SP-PAST-lend-ASP mouse shoes

"The cat lent the mouse the shoes."

b. Enzangu e-ka-gi-tiiz-a enkeito.

cat SP-PAST-lend-ocP 1-ASP shoes

"The cat lent it the shoes." 

c. Enzangu e-ka-zi-tiiz-a embeba. cat SP-PAST-lend-ocP 2-ASP mouse "The cat lent them to the mouse."
d. Enzangu e-ka-zi-gi-tiiz-a.
cat SP-PAST-lend-OCP 2-OCP 1-ASP
"The cat lent them to it."

It is important to mention that, as in example (34d), the order is always OCP2-OCP1. The reverse order is ungrammatical in Kihema, as illustrated by the example in (35):

(35) *Enzangu e-ka-gi-zi-tiiz-a.

cat SP-PAST-lend-ocP 1-OCP 2-ASP

"The cat lent them to it."

As was shown in Section 2.3 above, the Kihema verb heera "to give on behalf of someone" allows three NPs to appear with the verb. All three of these NPs can cliticize separately or together. Example (11) is repeated here as (36a), with the different cliticization possibilities given in (36b-e):
a. Omuseija a-ka-he-er-a omukazi omwaana omubazi. man SP-PAST- give-APP-ASP woman child medicine "The man gave for the woman to the child the medicine."
b. Omuseija a-ka-gu-he-er-a omukazi omwaana. man SP-PAST-OCP 3-give-APP-ASP woman child "The man gave it for the woman to the child."
c. Omuseija a-ka-mu-he-er-a omukazi amubazi. man SP-PAST-OCP 2-give-APP-ASP woman medicine "The man gave it for the woman the medicine."
d. Omuseija a-ka-mu-he-er-a omwaana amubazi. man SP-PAST-OCP 1-give-APP-ASP child medicine "The man gave for her the child the medicine."
e. Omuseija a-ka-gu-mu-mu-he-er-a . man SP-PAST-OCP 3-OCP 2-OCP 1-give-APP-ASP "The man gave it to it for her."

As I have mentioned in Section 2.1 above, a locative PP can appear along with the three NPs. The PP can also be represented as a pronominal clitic attached to the verb. In this case, the locative proform is a suffix:
a. Omuseija a-ka-he-er-a
omukazi omwaana amubazi ha irwaaro. man SP-PAST- give-APP-ASP woman child medicine at hospital "The man gave for the woman the child the medicine at the hospital." 
b. Omuseija a-ka-gu-mu-mu-here-er-a-yo.

man SP-PAST-OCP 3-OCP 2-OCP 1 -give-APP-ASP-OCP 4

"The man gave it to it for her there."

As was the case with the order of full object NPs, in Kihema OCPs appear in a certain order, depending on their thematic role and animacy. In addition, person and number determine the order of the OCPs.

\section{(i) Thematic role:}

As was mentioned earlier, if the benefactive is animate and the theme inanimate, the benefactive will precede the inanimate theme, and if the benefactive is inanimate and the theme animate, the animate theme will precede the inanimate benefactive. As for the order of OCPs, the inanimate will always precede the animate, regardless of whether it is benefactive or theme, as illustrated in (38) below. In cases where both NPs are animate, the animate theme OCP will precede the animate benefactive OCP.

$$
\begin{aligned}
& \text { a. Petero a-ka-let-er-a Yohaana amaarwa. } \\
& \begin{array}{l}
\text { Peter SP-PAST-bring-APP-ASP John beer } \\
\text { "Peter brought John beer." }
\end{array} \\
& \text { b. Petero a-ka-ga-mu-zan-ir-a. } \\
& \begin{array}{l}
\text { Peter SP-PAST-OCP 2-OCP 1-bring-APP-ASP } \\
\text { "Peter brought it to him." }
\end{array}
\end{aligned}
$$

(ii) Animacy:

In Kihema, animate complements always precede inanimate ones (see examples in (7) and (8) in section 2.3). As noted above, however, the reverse holds for OCPs. Animate OCPs always follow inanimate ones, as illustrated in (39):

a. Maria a-ka-et-er-a obugenyi abaana.

Maria SP-PAST- call-APP-ASP feast children

"Maria called the children for the feast."

b. Maria a-ka-bu-be-et-er-a.

Maria SP-PAST- OCP2-OCP1-call-APP-ASP

"Maria called them for it."

In (42a) the benefactive is inanimate and the theme is animate. In (42b) the inanimate benefactive OCP precedes the animate theme. This testifies that human beings have greater prominence over non-humans. There are other more compelling reasons, such as saliency and relevance, that are linked to perceptual principles and conceptualization. Thus in many Bantu languages, the prominent position immediately following the verb complex is reserved for the human noun (Morolong 1977). In languages such as Lingala ${ }^{3}$, for example, only humans can cliticize over non-humans, as illustrated in (40):

\footnotetext{
${ }^{3}$ Lingala is a Bantu language spoken in Congo-Kinshasa and Congo-Brazza-Ville.
} 
(40)

a. Petelo a-tind-el-a-ki Ngeleka mokanda.

(Lingala)

Peter SP-send-APP-ASP- PAST Ngeleka letter

"Peter sent the letter to Ngeleka."

b. Petelo a-mo-tind-el-a-ki mokanda.

Peter SP-OCP-send-APP-ASP-PAST letter

"Peter sent the letter to him."

c. *Petelo a-mo-tind-el-a-ki Ngeleka

Peter SP-OCP-send-APP-ASP-PAST Ngeleka

"Peter sent it to Ngeleka."

(iii) Person:

As far as person is concerned, a third person OCP must appear before a second or a first person OCP, as illustrated in (41) and (42):

a. Ananiya a-ka-n-tum-ir-a omukozi.

Ananiya SP-PAST-1 ${ }^{\text {st }}$-send-APP-ASP worker

"Ananiya sent the worker for me."

b. Ananiya a-ka-mu-n-tum-ir-a.

Ananiya SP-PAST- $\mathbf{3}^{\text {rd }}-\mathbf{1}^{\text {st }}$-send-APP-ASP

"Ananiya sent him for me."

c. *Ananiya a-ka-n-mu-tum-ir-a.

Ananiya SP-PAST-1 $\mathbf{1}^{\text {st }}-3^{\text {rd }}$-send-APP-ASP

"Ananiya sent me him."

(42) a. Ananiya a-ka-mu-ku-tum-ir-a. ${ }^{4}$

Ananiya SP-PAST- $3^{\text {rd }} \mathbf{- 2}^{\text {nd }}$-send-APP-ASP

"Ananiya sent him for you."

b. *Ananiya a-ka-ku-mu-tum-ir-a.

Ananiya SP-PAST-2 ${ }^{\text {nd }}-3^{\text {rd }}$-send-APP-ASP

"Ananiya sent him for you."

As such, constructions such as the one in (43) are impossible in Kihema, since the OCP order first $>$ third is ungrammatical:

(43) *Ananiya a-ka-n-mu-tum-ir-a.

Ananiya SP-PAST- $\mathbf{1}^{\text {st }}-3^{\text {rd }}$ - send-APP-ASP

"Ananiya sent him to it."

Furthermore, the second person OCP must precede the first person OCP, as illustrated in (44):

\footnotetext{
${ }^{4}$ In Kihema three OCPs can be marked on one verb. The third person OCP appears either with the first person or the second person. Constructions such as "Petero a-ka-mu-ku-n-det-er-a "Peter brought him to me for you" are impossible in Kihema.
} 
(44) a. Ananiya a-ka-ku-n-tum-ir-a.

Ananiya SP-PAST-2 ${ }^{\text {nd }}-\mathbf{1}^{\text {st }}$-send-APP-ASP

"Ananiya sent him to you."

b. *Ananiya a-ka-n-ku-tum-ir-a.

Ananiya SP-PAST-1 $\mathbf{1}^{\text {st }}-\mathbf{2}^{\text {nd }}$-send-APP-ASP

"Ananiya sent him to you."

As was already shown in example (37b), when two third person OCPs occur in the same sentence, the theme OCP will precede the benefactive:

a. Zonoberi a-ka-tum-ir-a Besueri omukozi.

Zonoberi SP-PAST-send-for-ASP Besueri worker

"Zonoberi sent the worker to Besueri."

b. Zonoberi a-ka-mu-mu-tum-ir-a.

Zonoberi SP-PAST- $\mathbf{3}^{\text {rd }}-\mathbf{3}^{\text {rd }}$-send-APP-ASP

"Zonoberi sent him to him."

However, when the first or the second person is the theme and the third person the benefactive, the latter will precede the former, as illustrated in (46) and (47):

(46) a. Maria a-ka-n-et-er-a obugenyi.

Maria SP-PAST-1 ${ }^{\text {st }}$ - call-APP-ASP feast

"Maria called me for the feast."

b. Maria a-ka-ku-et-er-a obugenyi.

Maria SP-PAST- $2^{\text {nd }}$ - call-APP-ASP feast

"Maria called you for the feast."

(47) a. Maria a-ka-bu-n-et-er-a

Maria SP-PAST- $\mathbf{3}^{\text {nd }}-\mathbf{1}^{\text {st }}$ - call-APP-ASP feast

"Maria called me for it."

b. Maria a-ka-bu-ku-et-er-a.

Maria SP-PAST- $3^{\text {rd }}-2^{\text {nd }}$ - call-APP-ASP feast

"Maria called you for it."

(iv) Number:

The order of numbers (plural and singular) of OCPs depends on semantic constraints. This means that the animate (benefactive) OCP will always appear after the inanimate (theme) regardless of its number, as illustrated in (48) and (49):

(48) a. Tibasima a-ka-gu-ur-a abakama ekyenzu.

Tibasima SP-PAST-buy-APP-ASP kings banana

"Tibasima bought the banana for the kings." 
b. Tibasima a-ka-ki-ba-gu-ur-a.

Tibasima SP-PAST-SG -PL -buy-APP-ASP

"Tibasima bought it for them."

c. $\quad$ *Tibasima a-ka-ba-ki-gu-ur-a.

Tibasima SP-PAST - PL -SG-buy-APP-ASP

"Tibasima bought it for them."

(49)

a. Tibasima a-ka-gu-ur-a omukama ebyenzu.

Tibasima SP-PAST-buy-APP-ASP king bananas

"Tibasima bought the bananas for the king."

b. Tibasima a-ka-bi-mu-gu-ur-a.

Tibasima SP-PAST -PL -SG -buy-APP-ASP

"Tibasima bought them for him."

c. *Tibasima a-ka-mu-bi-gu-ur-a.

Tibasima SP-PAST -SG- PL -buy-APP-ASP

"Tibasima bought for him them."

\subsection{Passivization}

Passivization takes place when the logical object of an active sentence in Kihema becomes the subject of the corresponding passive sentence, and the subject optionally becomes the oblique $\mathrm{PP}$ introduced by the preposition $n a$ (the so-called by-phrase). The passive suffix $-w$ - is attached to the verb. Kihema is particularly suited for demonstrating that almost any complement (including locatives, instrumentals, etc.) may be passivized. What I want to show here is that all NP objects that appear with a ditransitive verb in Kihema VP have the ability to passivize. In sentence (50), for example, both the theme and the benefactive NP can passivize:

$$
\begin{aligned}
& \text { a. Yohaana a-ka-h-a omwaana amata. } \\
& \text { John SP-PAST-give-ASP child milk } \\
& \text { "John gave the child the milk." } \\
& \text { b. Omwaana a-ka-heb-w-a amata (na Yohaana). } \\
& \text { child SP- PAST-give-PASS- ASP milk (by John) } \\
& \text { "The child was given the milk by John." } \\
& \text { Amata ga-ka-heb-w-a omwaana (na Yohaana). } \\
& \text { milk SP-PAST-give-PASS-ASP child (by John) } \\
& \text { "The milk was given to the child by John." }
\end{aligned}
$$

\subsection{Relativization}

Extraction of relative operators is also possible in Kihema. This means that an empty operator moves from object position to SpecCP of the relative clause. In Kihema, both the theme and the benefactive can be relativized, as illustrated in (51): 
a. N' amata ngu Yohaana ya-he-ir-e omwaana. 3S/PRES milk that John SP-give-APP-SUBJ child "It is the milk that John gave to the child."

b. N' omwaana ngu Yohaana ya-he-ir-e amata. 3S/PRES child that John SP-give-APP-SUBJ milk "It is the child that John gave the milk to."

\subsection{Theme deletion}

Theme deletion identifies the applied object of a ditransitive applicative construction as a direct object if the basic object (theme) can be omitted. Bresnan and Moshi (1990) state that theme deletion is one of the properties that attest that the applied object is a direct object. Theme deletion in Kihema is illustrated in example (52):
a. Kondo a-ka-ombek-er-a abagenyi enzu.
Kondo SP-PAST- build-APP-ASP guests house
"Kondo built the house for the guests."
b. Kondo a-ka-ombek-er-a abagenyi.
Kondo SP-PAST-OCP- build-APP-ASP guests
"Kondo built for the guests."

\section{Conclusion}

To summarize, this article provided Kihema data that illustrate the various arguments of the verb in the VP in Kihema. Firstly, the article discussed the possible complements that appear within the Kihema VP. Secondly, the article examined the different possible word orders of verbal complements in Kihema. Finally, the data show that Kihema is a genuine symmetrical language, like English and many Bantu languages, in that all post-verbal objects have the syntactic properties of cliticization, passivization and relativization. It can be concluded that all post-verbal NPs in Kihema are true direct (or primary) objects.

\section{References}

Baker, M. 1988. Incorporation: A Theory of Grammatical Function Changing. Chicago: Chicago University Press.

Bresnan, J. and L. Moshi. 1990. Object Asymmetries in Comparative Bantu Syntax. Linguistic Inquiry 21(2): 147-181.

Burzio, L. 1981. Intransitive Verbs and Italian Auxiliaries. Doctoral dissertation, MIT, Cambridge, Massachusetts.

Duranti, A. 1979. Object Clitic Pronouns in Bantu and the Topicality Hierarchy. Studies in African Linguistics 10: 31-45.

Duranti, A. and E.R. Byarushengo. 1977. On the Notion of 'Direct Object'. In E.R. Byarushengo, A. Duranti and L.M. Hyman (eds). Haya Grammatical Structure. Los Angeles: Department of Linguistics, University of Southern California, 45-71.

Gary, J.O. 1977. Implications for Universal Grammar of Object-Creating Rules in Luyia and Mashi. Studies in African Linguistics, Supplement 7: 85-95. 
Haegeman, L. 1991. Introduction to Government and Binding Theory. Oxford: Basil Blackwell.

Hodges, K. 1977. Causatives, Transitivity and Objecthood in Kimeru. Studies in African Linguistics, Supplement 7: 113-125.

Kimenyi, A. 1980. A Relational Grammar of Kinyarwanda. Berkeley: University of California Press.

Mchombo, S.A. 1993. On the Binding of the Reflexive and the Reciprocal in Chichewa. In S.A. Mchombo (ed). Theoretical Aspects of Bantu Grammar. Stanford: CSLI Publications, 181-204.

Morolong, M. 1977. Animacy, Objects and Clitics in Sesotho. Studies in African Linguistics 8(3): 199-217.

Mugisa, J.M. 2005. The Verb Phrase in Kihema. MA-thesis, University of KwaZulu-Natal.

Ngonyani, D. 1998. Properties of Applied Objects in Kiswahili and Kidendeule. Studies in African Linguistics 27(1): 67-93.

Nurse, D. and G. Philippson. 2003 (eds). The Bantu Languages. London: Routledge.

Spencer, A. 1991. Morphological Theory. Cambridge: Blackwell.

Vitale, A. 1981. Swahili Syntax. Dordrecht: Fortis.

Woolford, E. 2000. Agreement in Disguise. In V. Cartens and F. Parkinson (eds). Advances in African Linguistics. Trenton, NJ: Africa World Press, 103-117. Available online at http://people.umass.edu/ellenw/Woolford\%20Agreement\%20in\%20disguise.pdf

Woolford, E. 2001. Conditions on Object Agreement in Ruwund (Bantu). In E. Benedicto (ed). The UMass Volume on Indigenous Languages. Amherst, MA: GLSA. Available online at http://people.umass.edu/ellenw/Woolford\%20Conditions\%20Object\%20Agreement.

Zeller, J. 2004. Relative Clause Formation in the Bantu Languages of South Africa. Southern African Linguistics and Applied Language Studies 22(1-2): 75-93. 